Edith Cowan University

Research Online

Research outputs 2014 to 2021

2018

How does destination social responsibility contribute to environmentally responsible behaviour? A destination resident perspective

Lujun Su

Songshan (Sam) Huang

Edith Cowan University

Joanna Pearce

Edith Cowan University

Follow this and additional works at: https://ro.ecu.edu.au/ecuworkspost2013

Part of the Accounting Commons, and the Business Administration, Management, and Operations Commons

10.1016/j.jbusres.2018.02.011

This is an Author's Accepted Manuscript of: Su, L., Huang, S. S., \& Pearce, J. (2018). How does destination social responsibility contribute to environmentally responsible behaviour? A destination resident perspective. Journal of Business Research, 86, 179-1899. Available here.

This Journal Article is posted at Research Online.

https://ro.ecu.edu.au/ecuworkspost2013/4163 
Please cite this paper as: Su, L., Huang, S. \& Pearce, J. (2018). How does destination social responsibility contribute to environmentally responsible behaviour? A destination resident perspective. Journal of Business Research, 86, 179-189. DOI: 10.1016/j.jbusres.2018.02.01.

How does Destination Social Responsibility contribute to Environmentally Responsible Behaviour? A Destination Resident Perspective

\author{
Lujun $\mathrm{Su}, \mathrm{PhD}$ \\ Associate Professor in Marketing \\ School of Business \\ Central South University \\ Changsha, China \\ Email: sulujunslj@163.com \\ Songshan (Sam) Huang* \\ Professor of Tourism and Services Marketing \\ School of Business and Law \\ Edith Cowan University \\ Perth, Australia \\ Email: s.huang@ecu.edu.au \\ Joanna Pearce, $\mathrm{PhD}$ \\ Lecturer in Tourism and Hospitality Management \\ School of Business and Law \\ Edith Cowan University \\ Perth, Australia \\ Email: joanna.pearce@ecu.edu.au
}

*Corresponding author

Acknowledgments: This research was supported by the National Science Foundation of China (Grant No. 71573279, 71774176), the State Key Program of National Natural Science of China (Grant No. 714310006), the Key Laboratory of Hunan Province for Mobile Business Intelligence (2015TP1002), and Natural Science Foundation of Distinguished Young Scholars of Hunan Province (No. 2017JJ1032). 


\begin{abstract}
Based on stakeholder theory and social exchange theory, this study developed an integrated model to demonstrate that destination social responsibility (DSR) influences tourism impacts (both positive and negative impacts), overall community satisfaction, and both directly and indirectly influences resident environmentally responsible behaviour (ERB). The model was examined using a sample of 453 residents living on the Gulangyu Island, a famous island tourism destination of Xiamen, China. Results show that DSR enhances residents' perception of positive tourism impacts, improves overall community satisfaction and contributes to resident ERB. However, the effect of DSR on negative tourism impacts was not significant. Thus, positive tourism impacts and overall community satisfaction partially mediated the effect of DSR on resident ERB. The study findings offer both theoretical insights and practical implications on destination management and sustainable destination development.
\end{abstract}

Key words: Destination social responsibility; tourism impacts; community satisfaction; environmentally responsible behaviour; China

\title{
Introduction
}

Successful tourism development should be properly planned and managed (Byrd, Bosley, \& Dronberger, 2009; Southgate \& Sharpley, 2002; Yuksel, Bramwell, \& Yuksel, 1999). Destinations should develop policies and activities for their sustainable development (Byrd et al., 2009; Yuksel et al., 1999). As the development of a tourism destination is so reliant on environmental and cultural resources, these resources need to be managed and developed responsibly to achieve sustainable tourism development (Su, Huang, \& Huang, 2016). One means to achieve sustainable development is through socially responsible activities in the tourism destination (Su \& Swanson, 2017). Thus, some literature has emphasized the importance of destination social responsibility (DSR) for sustainable destination development (e.g., Su et al., 2016; Su \& Swanson, 2017).

Another key factor for sustainable destination development is on the stakeholders as important players in the process of sustainable development of destinations (Byrd et al, 2009). Sustainable destination development greatly relies on the destination' natural environment (Cheng \& Wu, 2015; Su \& Swanson, 2017); whether stakeholders adopt environmentally responsible behaviour or not has important implications on a destination's natural environment (Cheng \& 
Wu, 2015; Cheng, Wu, \& Huang, 2013; Ramkissoon, Smith, \& Weiler, 2013; Ramkissoon, Weiler, \& Smith, 2012, 2013; Su \& Swanson, 2017). However, when compared to tourists, destination residents may have greater impact on the natural environment at a destination because they have more extensive contact with the destination and their activities would exert a stronger impact upon the destination environment. Therefore, whether residents adopt ERB will seriously impact the natural environment of a destination, and in turn influence sustainable destination development.

DSR represents the responsibility for relevant stakeholders in the destination to generate economic benefits for local people, increase their well-being, and reduce negative economic, environmental and social impacts (Su et al., 2016). DSR can improve positive tourism impacts, and at the same time weaken negative tourism impacts perceived by residents. According to stakeholder theory, destination residents as the key stakeholder group of a destination, can get benefits from DSR. The gained benefits and cost reduction can lead to resident satisfaction with tourism development and the community (Ko \& Stewart, 2002; Vargas-Sa'nchez, PlazaMej1'a, \& Porras-Bueno, 2009; Vargas-Sa'nchez, Porras-Bueno, \& Plaza- Mej1'a, 2011). At the same time, social exchange theory posits that two parties make exchanges based on their benefits and costs, and exchanges can be achieved only if both parties feel that they benefit more from the exchange than they forsake. Thus, in order to gain more benefits from DSR, residents may adopt environmentally responsible behaviour to protect the destination's natural environment, which in turn contributes to sustainable destination development. However, to the best of our knowledge, few studies have empirically examined the relationships among DSR, tourism impacts, overall satisfaction with community and residents' environmentally responsible behaviour.

Drawing on the existing literature, especially on the work of Su et al. (2016), and based on stakeholder theory and social exchange theory, this study aims to develop and examine an integrated theoretical framework that has destination social responsibility (DSR) as a direct predictor of resident ERB, but also indirectly affect ERB through tourism impacts (positive and negative) and overall community satisfaction. Taken collectively, the contribution of this research for academics and practitioners is demonstrated in three aspects. Firstly, a contribution is made in the form of destination social responsibility (DSR), which is derived from CSR but with specific application to tourism destination management. Secondly, it is the first study of its kind to explore ERB from the resident perspective in examining whether DSR, tourism 
impacts and overall community satisfaction act as antecedents to ERB. Finally, through application of the integrated model, this study has explored the mediating roles of tourism impacts and overall community satisfaction between DSR and resident ERB.

\section{Theoretical Foundation and Hypotheses}

\section{Stakeholder theory and its application in tourism destination}

From a narrow sense, stakeholders are viewed as actors of organizations (Pfeffer \& Salancik, 1978; Zammuto, 1984); from a broad perspective, a stakeholder is defined as any group or individual who can impact, or is impacted by, the achievement of a corporation's purpose (Freeman, 1984). Based on Freeman’s (1984) definition, Donaldson and Preston (1995) identified that a stakeholder group or individual must have a legitimate interest in the organization. Stakeholder theory indicates that various individuals and groups could support and influence the organization, and could be reciprocally supported and impacted by it (Freeman, 1984).

Destinations can be defined as geographical locations that include all services and infrastructure needed for the visitors and offer tourist experience (Buhalis, 2000). The concept of stakeholder is relevant to destinations as a destination is perceived to be a network of interdependent and multiple stakeholders (Waligo, Clarke, \& Hawkins, 2013). Prior studies claimed that proactive efforts addressing all stakeholders' interests lead to significant returns to the destination as a whole (Formica \& Kothari, 2008). Yuksel et al. (1999) found that incorporating stakeholder views and caring for their interests can significantly reduce conflicts in the long term. Sautter and Leisen (1999) demonstrated that interested stakeholders tend to collaborate more in the tourism development process.

There are four main stakeholder groups in the destination context: residents, entrepreneurs, government officials, and tourists (Byrd et al., 2009; Goeldner \& Ritchie, 2003). Many studies treated residents as the core stakeholder group (e. g., Andereck \& Vogt, 2000; Byrd et al., 2009; Goeldner \& Ritchie, 2003; Gursoy et al., 2002; Su et al., 2016), and demonstrated that residents' perceptions of destination development and management would affect their attitudes and behaviors (Gursoy et al., 2002; Nunkoo \& Ramkissoon, 2010, 2011; Su et al., 2016). 


\section{Social exchange theory and its application in tourism}

Social exchange theory analyzes interaction between two parties by focusing on the benefits and costs accruing to each party in the exchange process. It argues that interactions are likely to continue if both parties feel that they are benefiting more than they lose in the exchanges. Ap (1992) regarded social exchange theory as "a general sociological theory concerned with understanding the exchange of resources between individuals and groups in an interaction situation” (p.668). Social exchange theory is widely used by researchers who attempt to study destination residents' attitudes and behaviors (Byrd et al., 2009; Gursoy et al., 2010; Lee et al., 2010; Nunkoo \& Ramkissoon, 2010, 2011). Especially, it provides a theoretical base for researching tourism impacts assessment by destination residents (Nunkoo \& Ramkissoon, 2010, 2011).

In the tourism literature, applications of social exchange theory confirm that resident behaviors are based on their assessments of the benefits and costs resulting from tourism development (Andereck et al., 2005; Long, Perdue, \& Allen, 1990; Nunkoo \& Ramkissoon, 2010, 2011). If residents assess that their gains are greater than the costs, they are willing to make the exchange with the industry (Nunkoo \& Ramkissoon, 2010, 2011).

\section{Destination Social Responsibility (DSR)}

A destination includes many tourism-related sectors, such as tour operation, ground transportation, airline, accommodation, restaurants, and travel agencies. Key players in these sectors face challenges in relation to social responsibility as major stakeholders that can influence the destination's economy, environment, culture, and society. Industry associations often develop self-regulatory guidelines to promote socially responsible business practices ( $\mathrm{Su}$ et al., 2016). Many studies have examined corporate social responsibility in the tourism industry, such as airlines (Lee, Seo, \& Sharma, 2013), hotel firms (Singal, 2014), restaurants (Kim \& Kim, 2014), and the accommodation sector (Garay \& Font, 2012). From the community perspective, residents perceive tourism impacts as the result of the collective activities of all stakeholders within a destination (Su et al., 2016). Thus, as Su et al. (2016) suggest, "the concept of CSR in the field of organisational behaviour is not completely suitable to the destination context” (p. 3). There is a need to propose destination social responsibility (DSR) as a distinctive concept. In accordance with Su et al. (2016), this study defines DSR as the "collective ideology and efforts of destination stakeholders to conduct socially responsible 
activities as perceived by local residents” (p. 3). According to stakeholder theory and social exchange theory, perceived DSR by residents will affect their perceptions of tourism impacts, and in turn influence their attitudes and behaviours.

\section{The Relationship between DSR and Tourism Impacts}

Tourism has a great potential to affect destination stakeholders through both positive and negative impacts (Byrd et al., 2009; Randle \& Hoye, 2016). Tourism impacts can be analysed from different perspectives, such as economic, social, cultural and environmental; and in each of these areas, the impacts can be either positive and negative (Kim , Uysal, \& Sirgy, 2013). For instance, tourism can help to improve the standard of living of a destination (Tosun, 2002), but it can also increase the price of goods and services (Weaver \& Lawton, 2001). In relation to social impacts, there is evidence that tourism contributes to crowdedness and deterioration of traditional culture (Andereck et al., 2005). On the other hand, tourism can also lead to better public infrastructure as well as recreational facilities (Nunkoo \& Ramkissoon, 2011a). While some researchers have demonstrated that tourism can be a means of revitalising cultures (Wang, Fu, Cecil, \& Avgoustis, 2006), others argue that tourism can be a "cultural exploiter" and disrupt the traditional cultural structures (Pearce, 1996). Finally, tourism can help to create good awareness of environmental protection and keep the local community environment clean (Ritchie, 1988). At the same time, tourism can cause damage to the natural environment through degradation of vegetation and disturbance of wildlife (Var \& Kim, 1989). Although numerous studies have explored the antecedents of tourism impacts (Nunkoo et al., 2010; Nunkoo \& Ramkissoon, 2011a), few studies have examined DSR as a determinant of tourism impacts and examined the relationship between them (Su et al., 2016).

Based on an extensive review of the literature, Dahlsrud (2008) identified 37 definitions of CSR and suggests that the definitions mainly include economic, social, environmental, stakeholder and voluntariness dimensions. DSR extends the definition and meaning of CSR in the tourism context by focusing on economic, social, environmental, stakeholder and voluntariness dimensions. DSR pertains to the responsibility for the impact of activities in a tourism destination on the environment, communities, stakeholders, employees, tourists, and all other members in the destination context. The purpose of DSR is to minimise the negative impacts in economic, environmental and social aspects, create more economic and wellbeing benefits for local residents, improve work conditions and industry access, engage community 
residents in decisions that influence their lives, protect natural environment resources, and maintain the diversity of the destination (Responsible Tourism in Destinations, 2002). Therefore, DSR can enhance tourism positive impacts, and reduce negative impacts. Thus we propose the following hypotheses:

$\mathrm{H}_{1}$ : DSR positively affects resident perception of positive tourism impacts

$\mathrm{H}_{2}$ : DSR negatively affects resident perception of negative tourism impacts

\section{The relationship between DSR and overall community satisfaction}

Community satisfaction is defined as residents' overall satisfaction with the community (Grzeskowiak, Sirgy, \& Widgery, 2003) and is seen as an important component of community planning and development (Nunkoo \& Ramkissoon, 2011b; Sirgy, Rahtz, Cicic, \& Underwood, 2000; Sirgy \& Cornwell, 2001). Ko and Stewart (2002) noted the need to include community satisfaction as a useful concept in the destination development context.

Based on stakeholder theory (Maignan, Ferrell, \& Ferrell, 2005) and institutional theory (Scott, 1987), business actions can be attractive to a customer not only as a consumer but also as a member to a societal group (Luo \& Bhattacharya, 2006). Accordingly, Daub and Ergenzinger (2005) propose the term "generalised customer”. A “generalised customer” does care about his or her own personal experience as a consumer; he or she also acts as an actual or potential member of some social or stakeholder groups that may influence a company's businesses. Holding the same view, Luo and Bhattacharya (2006) argue that products and services that are offered by socially responsible companies (compared to socially irresponsible counterparts) would be more likely to satisfy such "generalised" customers. Conversely, keeping a good record of CSR would generate a context in which consumers may form favourable evaluation of and attitudes toward the company (Luo \& Bhattacharya, 2006; Sen \& Bhattacharya, 2001).

DSR activities can lead to many benefits, such as increasing economic performance, protecting natural environment, and improving quality of life (Su et al., 2016). According to stakeholder theory, residents as the core group of destination stakeholders can gain the benefits from DSR activities, which could change residents' evaluation of the community they live in. Thus, the relationship between DSR and overall community satisfaction may be a positive one for two reasons. Firstly, DSR represents development equity and fairness towards local residents, which in turn leads to their satisfaction with the destination. Secondly, DSR activities can 
increase the perceived utility and value of the destination, which can strengthen residents' overall community satisfaction with the destination. Their perceived value can be in economic and non-economic forms (He \& Li, 2011); thus, DSR activities can add extra benefits/utilities to residents and increase their satisfaction. Based on these previous findings, the current study posits the following hypothesis:

$\mathrm{H}_{3}$ : DSR positively affects overall community satisfaction.

\section{The Relationship between DSR and Residents' Environmentally Responsible Behaviour}

Sustainable destination development is heavily dependent on the destination environment ( $\mathrm{Su}$ \& Swanson, 2017); accordingly, many scholars focus on environmentally responsible behaviour (Cheng \& Wu, 2015; Chiu et al., 2014; Han, 2015; Lee, 2011; Su \& Swanson, 2017). Environmentally responsible behaviour (ERB) is described as any behaviour an individual would undertake to conserve personal environments and/or solve environmental problems (Schultz, 2000; Stern, 2000). A review of prior studies has shown that ERB has been an area of research focus for a number of years. However, few studies have explored EBR and its antecedents from the resident perspective. As residents are a key stakeholder group of tourism destination (Su et al., 2016), whether they adopt ERB in their daily lives will heavily effect the destination environment and sustainable development.

In the marketing literature, studies have proven that companies that engage in CSR activities will elicit company-favouring responses from stakeholders (Bhattacharya, Korschun, \& Sen, 2009) in various stakeholder contexts (e.g. customer, employment, investment). For instance, in the consumer context, Sen and Bhattacharya (2001) suggested that the CSR record of a corporation positively influenced customer evaluations of the firm and in turn, their intention to purchase the firm's products. Similarly, in the employment context, CSR activities have been shown to not only positively influence the intention to seek a job within a corporation (Greening \& Turban, 2000; Turban \& Greening, 1997), but also positively influenced on-thejob behaviours such as interpersonal cooperation and job related effort (Bartel, 2001). In the investment context, Domini (1992) found that public firms' CSR activity can effectively attract investors to make investment decisions. Additionally, Sen, Bhattacharya and Korschun (2006) suggested that individuals might have greater intentions to buy a particular firm's stock when they were aware of large charitable gifts by the firm. 
Based on stakeholder theory, community residents as the core stakeholder group of the destination, can gain benefits from DSR initiatives, such as increasing income, enjoying a good natural environment, and improving quality of life. According to social exchange theory, when residents gain benefits from DSR initiatives, they would support the change with destination via feedback behaviour, such as support for tourism development, environmentally responsible behaviour. Thus, both the destination and residents can gain the benefits respectively from the exchange, and the exchange can sustain for a long time. Therefore, social exchange theory and stakeholder theory suggest that DSR initiatives could effectively motivate residents to foster favourable evaluations or perceptions, and in turn exhibit positive behaviours and intentions, such as ERB, to feedback to the destination. Thus, we present the following hypothesis:

$\mathrm{H}_{4}$ : DSR positively affects environmentally responsible behaviour.

\section{The Relationship between Tourism Impacts and Overall Community Satisfaction}

In Chenju Island, Korea, Ko and Stewart (2002) found residents' community satisfaction was closely related to tourism impacts; specifically, perceived positive impacts positively affected community satisfaction, and perceived negative impacts negatively affected community satisfaction. Similarly, Vargas-Sanchez, Plaza-Mejia and Porras-Bueno (2009) revealed a direct correlation between community satisfaction and perceived tourism impacts. In a later study, these authors further confirmed perception of impacts could increase residents' satisfaction with the community (Vargas-Sanchez, Porras-Bueno, \& Plaza-Mejia, 2011). Nunkoo and Ramkissoon (2011b) also indicated that tourism impacts could predict resident satisfaction with their community, with positive impacts leading to greater satisfaction and negative impacts leading to less satisfaction with their community.

Actually, residents are the key group of destination stakeholders. Positive tourism impacts would generate benefits to residents, and negative tourism impacts would cause a sense of loss to them. Generally, residents would expect to gain benefits from tourism development. When residents' expectation is met in the process of tourism development, they tend to be satisfied with the community. On the contrary, if they perceive loss from negative tourism impact, they may be dissatisfied with their community. Therefore, based on stakeholder theory and previous empirical findings from the literature, the following hypotheses are proposed:

$\mathrm{H}_{5}$ : Positive tourism impacts positively affect overall community satisfaction.

$\mathrm{H}_{6}$ : Negative tourism impacts negatively affect overall community satisfaction. 


\section{The Relationship between Tourism Impact and Residents' Environmentally Responsible}

\section{Behaviour}

Various studies have suggested that tourism development can bring many benefits for community residents, including the increase of employment opportunities (Dyer, Gursoy, Sharma, \& Carter, 2007; Nunkoo \& Ramkissoon, 2011a) and standard of living (Nunkoo \& Ramkissoon, 2011a), more businesses and investment opportunities for local people (Dyer et al., 2007; Kwan \& McCartney, 2005; Nunkoo \& Ramkissoon, 2011a), promotion of local economy (Gursoy \& Rutherford, 2004), and improved infrastructure (Nunkoo \& Ramkissoon, 2011a). Additionally, previous studies have suggested that residents' perceptions of positive tourism impacts positively influence their attitudes and behaviours, including support for tourism development (Andereck et al., 2005; Gursoy et al., 2002; Gursoy \& Rutherford, 2004; Lee, 2011; Nunkoo et al., 2010; Nunkoo \& Ramkissoon, 2011a). Conversely, perceived negative impacts of tourism, such as increasing environmental pollution (Gursoy \& Rutherford, 2004; Nunkoo \& Ramkissoon, 2011a), increases in the price of land and property (Lord, Greenidge, \& Devonish, 2011; Nunkoo \& Ramkissoon, 2011a) and increased crime rate (Gursoy \& Rutherford, 2004; Miman \& Pizam, 1988), may affect the perception of benefits that residents receive from tourism and may result in lack of support for sustainable tourism development.

According to social exchange theory, when residents perceive benefits gained from positive tourism impacts, they would adopt positive behaviours including ERB toward the destination, so that they can continue the exchange with the destination. On the contrary, when residents perceive loss from negative tourism impacts, they may stop ERB behaviours to the destination. Thus, based on previous literature and social exchange theory, it can be inferred that positive tourism impacts can promote residents' ERB, and negative tourism impacts can restrain residents’ ERB. Therefore, the following hypotheses are proposed:

$\mathrm{H}_{7}$ : Positive tourism impacts positively affect environmentally responsible behaviour. $\mathrm{H}_{8}$ : Negative tourism impacts negatively affect environmentally responsible behaviour. 


\section{The Relationship between Overall Community Satisfaction and Residents' Environmentally}

\section{Responsible Behaviour}

To the best of our knowledge, no studies have examined the relationship between overall community satisfaction and ERB from the perspective of the destination residents. Previous studies have shown, however, that tourist satisfaction can garner positive attitudes and behaviours (Chiu et al., 2014; Higham \& Carr, 2002; Lee \& Moscardo, 2005). For example, Orams (1995) suggested that tourist satisfaction in ecotourism development is dependent on experiences, and if tourists are satisfied with an experience, they will change their behaviour. In a study on the Galapagos Island National Park, Powell and Ham (2008) found that guiding in ecological areas is related to tourist satisfaction with the ecotourism experience, which in turn enhances the understanding of and support for ecological conservation and lead to ERB. Additionally, in a national park context, Chiu et al. (2014) directly examined the relationship between tourist satisfaction and ERB; the study showed that tourist satisfaction can promote ERB, and also plays a partial mediating role between perceived value and ERB.

Besides, from destination resident perspective, previous studies generally supported that residents' satisfaction with community is an important antecedent of residents' behaviours, such as support for tourism development (e.g., Nunkoo \& Ramkissoon, 2011b; VargasSanchez, Plaza-Mejia, \& Porras-Bueno, 2009; Vargas-Sanchez, Porras-Bueno, \& Plaza-Mejia, 2011). Both support for tourism development and ERB can be regarded as residents' positive behaviour toward the destination, aiming to achieve sustainable destination development. As such, we argue that residents' overall community satisfaction with the destination can enhance their ERB, and present the following hypothesis:

$\mathrm{H}_{9}$ : Overall community satisfaction positively affects environmentally responsible behaviour.

The theoretical model underlying influences of DSR on ERB via tourism impacts (both positive and negative) and overall community satisfaction is depicted in Figure 1. The ERB construct is incorporated into the conceptual model as the key outcome variable to capture the complete effect of DSR. Tourism impacts (both positive and negative) and overall community satisfaction are proposed as mediators for the relationship between DSR and ERB. 


\section{Methodology}

\section{Construct Measurements}

According to the analysis of CSR definitions by Dahlsrud (2008), CSR includes five dimensions - environmental, social, economic, stakeholder and voluntariness. Many studies have adopted some of these dimensions (Lee, Kim, Lee, \& Li, 2012; Lichtenstein, Drumwright, \& Braig, 2004; Su, Huang, van der Veen, \& Chen, 2014; Walsh \& Bartikowski, 2013). Based on these previous CSR studies and the definition of DSR, the present study measures DSR using five adapted items which captures the environmental, social, economic, stakeholder and voluntariness dimensions. These have shown to have good validity and reliability based on a previous study in an Ancient Town destination (Su et al., 2016).

Tourism impacts include positive impacts and negative impacts, with each area containing three items adopted from Gursoy and Rutherford (2004), Gursoy et al. (2002), and Nunkoo and Ramkissoon (2011b). Three items adopted from Grzeskowiak et al. (2003) and Nunkoo and Ramkission (2011b) were used to measure overall community satisfaction. For ERB, six items were adapted and modified from Thapa's (2010) and Smith-Sebasto and D'Costa's (1995) studies. These items possessed adequate qualities in terms of reliability and validity in an island tourism context (Cheng, Wu \& Huang, 2013) and an ecotourism context (Chiu, Lee \& Chen, 2014). The three items of overall community satisfaction were measured on a 7-point Likerttype scale where 1 represents "very dissatisfied" and 7 represents "very satisfied”. All the other measurement items were measured on a 7-point Likert-type scale, with 1 being "strongly disagree” and 7 indicating “strongly agree”.

\section{Pre-test of the Measurements}

A Chinese questionnaire was developed with reference to the above-mentioned literature of measurement items. The English items were translated into Chinese and further refined in the study context to construct the questionnaire. Before the formal questionnaire was distributed, a pre-test of the measurement items was conducted. Firstly, four tourism management professors were asked to provide feedback regarding the wording, layout, and ease of understanding of the measurement items. The questionnaire was revised based on their feedback. Secondly, the revised questionnaire was pre-tested using a convenience sample of 
40 undergraduate students from a university in China. Results of measurement items were analysed for the reliability using Cronbach's Alpha, and validity via standard factor loading. The analysis results indicated that Cronbach Alpha for each latent variable was larger than 0.700, representing good reliability (Nunally, 1978). Standard factor loadings for each item was larger than 0.500 and significant at the 0.001 level, suggesting good validity (Anderson \& Gerbing, 1988).

\section{Study Site and Data Collection}

Data for this current study was collected via a questionnaire survey on the residents of Gulandyu Island, Xiamen, Fujian, which is a famous island destination in China. Gulandyu Island is located southwest of Xiamen City and visitors can reach it by a five-minute steamship ferry ride from the Xiamen City. The island is on China's list of National Scenic Spots, well known for its delicate beauty, ancient relics, and its architecture.

The sampling frame of this study consisted of individuals who lived in the Gulangyu Island. As we did not have the access to a household list of the Island, we used a systematic sampling approach by selecting every second household on each street in the Island. The questionnaires were distributed by 9 trained college students who majored in tourism management. The 9 college students were divided into three groups. The groups conducted the survey door-bydoor on the streets. The respondents were first asked whether they are residents of Gulangyu, and whether they would participate in the survey. With affirmative answers, the field researchers would give the questionnaire to the respondents and stay nearby until the respondents have completed the questionnaire. If needed, the field researchers would provide clarifications and answer questions regarding the questionnaire. Participation in this study was voluntary and participants' names and contact information were not requested in order to protect their privacy. The field researchers collected the completed questionnaires, and briefly checked the completeness of the responses at the survey site. The survey was conducted from 18 March to 26 November 2016. A total of 500 questionnaires were distributed and 466 were returned to the researchers (93.2\% response rate). Of these, 453 were complete responses. 


\section{Empirical Analysis and Results}

\section{Sample Profile}

Respondents' demographic profiles are presented in Table 1. The sample had a relatively balanced male-to-female ratio (48.8\% vs. $51.2 \%$ ). The highest percentage of respondents were in the 25-44 age range (33.6\%), with the lowest percentage in the 65 or older age range $(12.4 \%)$. Most respondents had a high school/technical school or undergraduate/associate degree level of education, with $7.9 \%$ having a postgraduate degree. Over $50 \%$ of respondents indicated that they received a monthly income between RMB 3000-4999 (approx. US\$436-726) (Table 1).

[Table 1 near here]

\section{Common Method Variance Test}

We first used the Harman's single factor test to examine the issue of common method variance (CMV). As the result shows that all the measurement items are not likely to load on one single factor, we claim that CMV is not a pervasive issue in this study (Chang, Witteloostuijn, and Eden, 2010). Besides, based on the procedure and method of common method variance test in different research contexts recommended by Podsakoff et al. (2003), we constructed a common method variance measurement model allowing all the measurement items to not only load on the latent constructs they are supposed to measure, but also load unanimously on a common method latent factor. We then compared this model with the measurement model without the latent method factor to see if common method variance is an issue. The results show that the fit indices of the common method variance measurement model improved somewhat, but the improvement is not obvious. This further showed that common method variance is not a serious issue in this study.

\section{Measurement Model Test}

Before the analysis, we checked whether the data were normally distributed. The results showed that the Skewness values of all items ranged from -1.794 to 1.593 , all of which were less than 3 in absolute value. The Kurtosis values of all items ranged from -.408 to 3.816, all below 10 in absolute value. According to Kline (1998), the data in this study did not violate the assumption of normal distribution required in the subsequent analyses. 
To address the research questions and test the research hypotheses, a two-step analysis process was adopted. Confirmatory factor analysis was employed as the first step to verify the measurement model; then, the proposed inter-variable relationships were tested as the second step.

The fit indices of the measurement model (Table 2) suggest the model fits the data well. All the indices are acceptable following $\mathrm{Hu}$ and Bentler's (1999) model evaluation criteria. Cronbach Alpha coefficients and composite construct reliability were used to measure reliability. Results in Table 3 show the Cronbach's Alpha values of the constructs ranged from 0.846 to 0.948 , all above the threshold of 0.700 . Additionally, the composite reliability of the constructs ranged from 0.854 to 0.948 . This demonstrates adequate internal consistency of the multiple items for measuring each construct (Hair, Anderson, Tatham, \& Black, 1998).

[Table 2 near here]

Validity analyses include examining both convergent validity and discriminant validity. Convergent validity was assessed by the contribution of measurement items to their corresponding constructs. Convergent validity was satisfied as the factor loadings for all items were above 0.591 and were significant at the 0.001 level (Anderson \& Gerbing, 1988). Additionally, the average variance extracted (AVE) values of all constructs ranged from 0.546 to 0.860, higher than the threshold value of 0.500 (Fornell \& Larcker, 1981; Hair et al., 1998). These indicate sufficient convergent validity of the measurement items.

Discriminant validity means that items measuring one construct do not significantly load on another construct. This was tested by comparing the square root of the average variance extracted (AVE) with the correlation coefficients between each pair of the constructs (Fornell \& Larcker, 1981). According to Fornell and Larcker (1981), if the square roots of AVEs are greater than the correlations between any pair of constructs, discriminant validity is satisfied. As indicated in Table 4, the square roots of AVEs were greater than the correlation coefficients, showing satisfactory discriminant validity of the measurements.

[Table 3 near here]

[Table 4 near here] 


\section{Structural Model Test}

The fit indices for the structural model $\left(\chi_{2} / \mathrm{df}=2.655\right.$; $\mathrm{RMR}=0.097$; RMSEA $=0.061, \mathrm{GFI}=$ 0.917; AGFI = 0.889; NFI = 0.939; RFI = 0.927; IFI = 0.961; $\mathrm{TLI}=0.953 ; \mathrm{CFI}=0.961$ ) show that the model fit the data sufficiently (Hu and Bentler, 1991). Table 5 shows the results of the structural model test. The effects of destination social responsibility (DSR) on positive impacts $\left(\lambda_{21}=0.448, \mathrm{p}<0.001\right)$, overall community satisfaction $\left(\lambda_{41}=0.205, \mathrm{p}<0.001\right)$, and ERB $\left(\lambda_{51}\right.$ $=0.212, \mathrm{p}<0.001$ ) were all positive and significant, providing support for $\mathrm{H}_{1}, \mathrm{H}_{3}$ and $\mathrm{H}_{4}$. However, the path coefficient from DSR to negative impacts $\left(\lambda_{31}=-0.38, \mathrm{p}>0.05\right)$ was not significant, indicating that $\mathrm{H}_{2}$ was not supported. Therefore, perceived destination social responsibility appeared to be an important antecedent to positive impacts, overall community satisfaction and ERB.

Positive impacts had a significant positive effect on overall community satisfaction $\left(\beta_{42}=\right.$ 0.539, $\mathrm{p}<0.001)$ and $\mathrm{ERB}\left(\beta_{52}=0.163, \mathrm{p}<0.05\right)$, thus providing support for $\mathrm{H}_{5}$ and $\mathrm{H}_{7}$. Negative impacts had a significant negative effect on overall community satisfaction $\left(\beta_{43}=-0.182\right.$, $\mathrm{p}<0.001)$ and ERB $\left(\beta_{53}=-0.099, \mathrm{p}<0.05\right)$; thus, $\mathrm{H}_{6}$ and $\mathrm{H}_{8}$ were supported. Finally, overall community satisfaction had a significant positive effect on $\operatorname{ERB}\left(\beta_{54}=0.255, \mathrm{p}<0.001\right)$. $\mathrm{H}_{9}$ was supported. Figure 2 shows the same results in the diagram of the structural model.

[Table 5 near here]

[Figure 2 near here]

\section{Explanation Power of the Model}

According to Cohen (1988), a model's explanation power can be assessed by the $\mathrm{R}^{2}$ of its major endogenous variables in the model. An $\mathrm{R}^{2}$ value of $.01, .09$ and .25 could be used as threshold value to indicate small, medium, and large effect in the model, respectively. Judging by the $\mathrm{R}^{2}$ values of the endogenous variables, the structural model explained $20.1 \%, 47.0 \%$, and $29.2 \%$ of the variance for positive impacts, overall community satisfaction, and environmentally responsible behaviour, respectively. However, the amount of variance explained for negative impacts is low $(0.1 \%)$, meaning that other variables not captured in the model would better predict negative impacts. These $\mathrm{R}^{2}$ values generally indicate that the model possesses good explanatory power. 


\section{Direct, Indirect and Total effects}

The direct, indirect and total effects among the constructs are shown in Table 6. Among all the antecedents of ERB, overall community satisfaction had the largest direct effect $\left(0.255^{* * *}\right)$ on ERB. However, DSR had a significant indirect effect (0.193***) on ERB through positive tourism impacts and overall community satisfaction. Considering both indirect and indirect effects, DSR exerted the largest total effect $\left(0.405^{* * *}\right)$ on ERB among all the antecedent variables of ERB. Conversely, DSR did not have a significant indirect effect on ERB via negative impacts of tourism. This indicates that positive tourism impacts and overall community satisfaction partially mediate the effect of DSR on ERB. Additionally, based on the total effects, there are differentiating effects of positive impacts and negative impacts on ERB. The total effect of positive impacts on ERB was much larger in its magnitude than that of negative impacts on ERB.

\section{[Table 6 near here]}

\section{Discussion and Conclusions}

The present study developed and tested an integrated model to explore how perceived DSR contributes to resident ERB via perceived tourism impacts and overall community satisfaction. The integrated model was examined empirically in a famous island destination in Fujian, China. Using stakeholder theory and social exchange theory as the theoretical foundations, the study confirmed that DSR, as perceived by destination community residents in the process of tourism development, is important in shaping residents’ perceived tourism impacts, satisfaction and ERB.

Few studies have examined the relationship between DSR and tourism impacts (Su et al., 2016). In the current study, a significant relationship was found between DSR and positive tourism impacts; however, no significant relationship was found between DSR and negative tourism impacts. This finding is similar to those of previous studies (Ko \& Stewart, 2002; Lee 2013; Su et al., 2016). Specifically, Ko and Stewart (2002) found a significant relationship between personal benefits from tourism and perceived positive impacts of tourism; however, no significant relationship was found between personal benefits from tourism development and perceived negative impacts of tourism. Similarly, Lee (2013) used community attachment and involvement as the antecedents of perceived benefits and costs and found both community 
attachment and involvement significantly affected perceived benefits; however, neither community attachment nor community involvement significantly influenced perceived costs. A possible explanation for this result is that negative tourism impacts come from the tourism development itself and some negative impacts, such as over-crowdedness and rising prices, may be perceived as inevitable in tourism development. As such, residents may have psychologically rationalised negative tourism impacts. On the other hand, in developing countries, residents may favour tourism as a means of development and thus put more weight on positive impacts in their evaluation of tourism impacts.

Though previous literature has demonstrated that local residents are the key stakeholder group of a destination and whether they will adopt ERB in their daily life will heavily influence a destination's environment and sustainable development, few studies have examined ERB and its antecedents in the destination context from the resident perspective. This study thus addressed this research gap. It formulates DSR as an antecedent of overall community satisfaction and residents' ERB based on stakeholder theory and social exchange theory. The empirical results suggest that DSR activities are important ways to improve resident satisfaction and motivate them to adopt ERB. By applying socially responsible destination management measures and procedures, destinations can not only improve the sense of wellbeing and satisfaction of local residents, but also effectively encourage residents' ERB, eventually contributing to sustainable destination development.

The present study found positive tourism impacts positively affected overall community satisfaction, and negative tourism impacts negatively affected overall community satisfaction. Furthermore, positive impacts had a stronger effect on community satisfaction than negative impacts. This result is consistent with Ko and Stewart (2002), who found that perceived tourism impacts (both positive and negative impacts) were closely related to overall community satisfaction and that perceived positive impacts had a stronger effect on overall community satisfaction than perceived negative impacts. This result highlights the importance of promoting positive tourism impacts in the process of destination development.

Based on social exchange theory, this study examined the effect of perceived tourism impacts and overall community satisfaction on residents' ERB. The results indicate that perceived positive impact and overall community satisfaction had a significant effect on residents’ ERB, and perceived negative impacts negatively affected residents' ERB. This indicates that 
residents' perception of tourism impacts is one of the main predictors of their attitudes and behaviours (Byrd \& Gustke, 2004). Among the four antecedent constructs to ERB, overall community satisfaction had the strongest direct effect, while perceived negative tourism impacts had the weakest negative effect (in magnitude) on residents' ERB. These findings further confirm that community satisfaction plays an important role in forming resident behaviour (Ko \& Steward, 2002).

Moreover, the findings indicate that perceived positive impacts and overall community satisfaction played a mediating role between DSR and resident ERB. This shows consistency to previous studies (e.g. Lee, 2013; Nunkoo and Ramkissoon, 2011b) which found that perceived benefits partially mediated the effect of community attachment and support for sustainable tourism development. Consequently, the study identified four paths in relation to the effect of DSR on residents' ERB: 1) DSR $\rightarrow$ residents' ERB; 2) DSR $\rightarrow$ positive impacts $\rightarrow$ residents' ERB; 3) DSR $\rightarrow$ overall community satisfaction $\rightarrow$ residents' ERB; 4) DSR $\rightarrow$ positive impacts $\rightarrow$ overall community satisfaction $\rightarrow$ residents' ERB. These four paths represent the formation processes of residents' EBR which can also be supported by Cognitive Appraisal Theory (Ellsworth \& Scherer, 2003). According to Cognitive Appraisal Theory, personal evaluation/perception as the result of an information processing activity determines the emotions on the benefits and goals sought, which in turn lead to behavioural responses. In the current study, DSR can be viewed as a stimulus (S) to residents, overall community satisfaction is the internal state $(\mathrm{O})$ of residents, and ERB is the response of residents. Thus, the four paths showing the formation processes of residents' ERB are also consistent with the Stimulus-Organism-Response (S-O-R) Framework (Mehrabian \& Russell, 1974). Following Cognitive Appraisal Theory and Stimulus-Organism-Response (S-O-R) Framework, the findings of this study can be adequately explained.

Taken collectively, these paths further highlight the importance of DSR in sustainable destination development. DSR appears to be an important concept on which both researchers and industry practitioners can act. The confirmed relationships between DSR and wellresearched destination tourism concepts like tourism impacts and resident satisfaction also increased the theoretical relevance of DSR in the destination management literature. 


\section{Management Implications}

This current study has shown that DSR has significant effects on perceived tourism impacts, overall community satisfaction and resident ERB, which further confirm that DSR activities are important in sustainable destination development (Su \& Swanson, 2017). DSR should be taken as a "win-win” strategy for all stakeholders involved in the destination (i.e. government, firms and local residents). As such, managers should invest more on DSR initiatives and communicate these initiatives via various channels, especially social media, to local residents. This will in turn influence residents’ perceptions and improve their ERB.

DSR can be an important topic in the dialogue between destinations and their stakeholders. As a DSR initiative, destination tourism administrations may encourage tourism firms and operators to contribute to community improvement. Governments could turn some of their revenue into a "Social Responsibility Management Fund (SRMF)" to execute social responsibility initiatives. Authorities could communicate with residents regarding tourism development to make sure that development in the destination is perceived to lead to more positive than negative impacts to local communities.

Findings suggest that residents' perception of positive tourism impacts can make them to adopt ERB. On the contrary, perception of negative tourism impacts results in less ERB. Therefore, relevant destination management policies should be put in place to enhance positive tourism impacts while eliminating the negative impacts in order to encourage residents' ERB. Especially, destination authorities should build an effective benefit-sharing mechanism to ensure that the majority of residents can share the benefits from tourism development. This will enhance the perception of positive tourism impacts, which leads to more resident ERB in return.

Considering the important role of overall community satisfaction to resident ERB, destination managers and marketers should execute a resident satisfaction strategy. To implement the strategy, managers and marketers should provide satisfactory tourism environment, infrastructure, and service, and monitor the change of resident satisfaction. At the same time, reasons of dissatisfaction should be identified and addressed in order to promote residents' ERB. 


\section{Limitations and Directions for Future Research}

This study has several limitations. First, similar to previous ERB studies, this study applied a self-report measurement of residents' ERB. Due to the effect of social desirability, it is possible that ERB may be overestimated in some individual responses, and thus may not accurately reflect actual behaviour (Corral- Verdugo, 1997; Lee, 2011; Lee, Jan \& Yang, 2013; Serenari, Leung, Attarian, \& Franck, 2012). Future research should seek more reliable measures to assess residents’ actual ERB.

Second, the study used a convenience sample of domestic Chinese Island residents and thus the findings may be limited in generalisability. Future studies may consider more generalizable random sampling techniques as well as a more geographically and ethnically diverse population. Third, this study measures DSR as a uni-dimensional construct. In the marketing literature, corporate social responsibility has often been operationalised as multi-dimensional (Lee et al., 2012). Various dimensions of the DSR construct may have differentiated effects on tourism impacts, support for tourism and quality-of-life. Thus, future research may further conceptualise and operationalise DSR as a multi-dimensional construct and test each dimension's role in the proposed relationships.

\section{References}

Andereck, K. L., Valentine, K., Knopf, R., \& Vogt, C. A. (2005). Residents' perceptions of community tourism impacts. Annals of Tourism Research, 32, 1056-1076.

Andereck, K. L., \& Vogt, C. A. (2000). The relationship between residents' attitudes towards tourism and tourism development options. Journal of Travel Research, 39, 27-36.

Anderson, J. C., \& Gerbing, D. W. (1988). Structural equation modeling in practice: A review and recommended two-step approach. Psychological Bulletin, 103(3), 411-423.

Ap, J. (1992). Residents' perceptions on tourism impacts. Annals of Tourism Research, 19(4), 665-690.

Bartel, C. A. (2001). Social comparisons in boundary spanning work: Effects of community outreach on members' organizational identity and identification. Administrative Science Quarterly, 46(3), 379-414.

Bhattacharya, C. B., Korschun, D., \& Sen, S. (2009). Strengthening stakeholder-company relationships through mutually beneficial corporate social responsibility initiatives. Journal of Business Ethics, 85, 257-272.

Buhalis, D. (2000). Marketing the competitive destination of the future. Tourism Management, 21(1), 97-116.

Byrd, E. T., \& Gustke, L. D. (2004). Identifying tourism stakeholder groups based on support for sustainable tourism development and participation in tourism activities. In F. D. Pineda \& C. A. Brebbia (Eds.), Sustainable tourism: The sustainable world (pp. 97108). London: WIT Press. 
Byrd, E. T., Bosley, H.E., \& Dronberger, M. G. (2009). Comparisons of stakeholder perceptions of tourism impacts in rural eastern North Carolina. Tourism Management, 30, 693-703.

Chang, S.-J., Witteloostuijn, A., \& Eden, L. (2010). From the editors: Common method variance in international business research. Journal of International Business Studies, 41, 178-184.

Cheng, T.-M., \& Wu, H. C. (2015). How do environmental knowledge, environmental sensitivity, and place attachment affect environmentally responsible behavior? An integrated approach for sustainable island tourism. Journal of Sustainable Tourism, 23(4), 1-20.

Cheng, T.-M., Wu, H. C., \& Huang, L. M. (2013). The influence of place attachment on the relationship between destination attractiveness and environmentally responsible behavior for island tourism in Penghu, Taiwan. Journal of Sustainable Tourism, 21(8), 1166-1187.

Chiu, Y.-T. H., Lee, W.-I., \& Chen, T.-H. (2014). Environmentally responsible behavior in ecotourism: Antecedents and implications. Tourism Management, 40, 321-329.

Cohen, J. (1988). Statistical power analysis for the behavioral sciences (2nd ed.). Hillsdale, NJ: Lawrence Erlbaum Associates.

Corral-Verdugo, V. (1997). Dual "realities" of conservation behavior: Self-reports vs. observations of reuse and recycling behaviour. Journal of Environmental Psychology, $17,135-145$.

Dahlsrud, A. (2008). How corporate social responsibility is defined: an analysis of 37 definitions. Corporate Social Responsibility and Environmental Management, 15(November), 1-13.

Daub, C.-H., \& Ergenzinger, R. (2005). Enabling sustainable management through a new multi-disciplinary concept of customer satisfaction. European Journal of Marketing, 39(9/10), 998-1012.

Domini, A. (1992). What is social investing? Who are social investors? In P. Kinder, S. Lydenberg \& A. Domini (Eds.), The Social Investment Almanac. New York, NY: Henry Holt and Company.

Donaldson, T., \& Preston, L. E. (1995). The stakeholder theory of the corporation: Concept, evidence, and implications. Academy of Management Review, 20(1), 65-91.

Dyer, P., Gursoy, D., Sharma, B., \& Carter, J. (2007). Structural modeling and resident perceptions of tourism and associated development on the Sunshine Coast, Australia. Tourism Management, 28, 409-422.

Ellsworth, P. C., \& Scherer, K. R. (2003). Appraisal processes in emotion. Handbook of Affective Sciences, 572-595.

Formica, S., \& Kothari, T. H. (2008). Strategic destination planning: Analyzing the future of tourism. Journal of Travel Research, 46, 355-367.

Fornell, C., \& Larcker, D. F. (1981). Evaluating structural equation models with unobservable variables and measurement error. Journal of Marketing Research, 18(1), 39-50.

Freeman, R.E. (1984). Strategic management: A stakeholder approach. Boston, MA: Pitman.

Garay, L., \& Font, X. (2012). Doing good to do well? Corporate social responsibility reasons, practices and impacts in small and medium accommodation enterprises. International Journal of Hospitality Management, 31(2), 329-337.)

Goeldner, C. R., \& Richie, J. R. B. (2003). Tourism principles, practices and philosophies. 9th Ed. Hoboken, N. J.: Wiley.

Greening, D. W., \& Turban, D. B. (2000). Corporate social performance as competitive advantage in attracting a quality workforce. Business \& Society, 39(3), 253-280. 
Grzeskowiak, S., Sirgy, J. M., \& Widgery, R. (2003). Residents' satisfaction with community services: Predictors and outcomes. Journal of Regional Analysis and Policy, 33(1), 136.

Gursoy, D., \& Rutherford, D. G. (2004). Host attitude toward tourism: An improved structural model. Annals of Tourism Research, 31, 495-516.

Gursoy, D., Chi, C. G., \& Dyer, P. (2010). Local's attitudes toward mass and alternative tourism: The case of Sunshine Coast, Australia. Journal of Travel Research, 49, 381394.

Gursoy, D., Jurowski, C., \& Uysal, M. (2002). Residents attitudes: A structural modelling approach. Annals of Tourism Research, 29(1), 790-105.

Hair, J. F., Anderson, R. E., Tatham, R. L., \& Black, W. C. (1998). Multivariate data analysis. Englewood Cliffs, NJ: Prentice Hall.

Han, H. (2015). Travelers' pro-environmental behavior in a green lodging context: Converging value-belief-norm theory and the theory of planned behavior. Tourism Management, 47, 164-177.

He, H., \& Li, Y. (2011). CSR and service brand: The mediating effect of brand identification and moderating effect of service quality. Journal of Business Ethics, 100, 673-688.

Higham, J., \& Carr, A. (2002). Ecotourism visitor experiences in Aotearoa/New Zealand: Challenging the environmental values of visitors in pursuit of pro-environmental behavior. Journal of Sustainable Tourism, 10(4), 277-294.

Hu, L. T., \& Bentler, P. M. (1999). Cutoff criteria for fit indices in covariance structure analysis: conventional criteria versus new alternatives. Structural Equation Modeling, 6(1), 1-55.

Kim, K., Uysal, M., \& Sirgy, J. M. (2013). How does tourism in a community impact the quality of life of community residents? Tourism Management, 36, 527-540.

Kim, M., \& Kim, Y. (2014). Corporate social responsibility and shareholder value of restaurant firms. International Journal of Hospitality Management, 40, 120-129.

Kline R B. (1998). Principles and Practice of Structural Equation Modeling. New York: The Guilford Press.

Ko, D. W., \& Stewart, W. P. (2002). A structural model of residents' attitude for tourism development. Tourism Management, 23, 521-530.

Kwan, F. V. C., \& McCartney, G. (2005). Mapping resident perceptions of gaming impacts. Journal of Travel Research, 44, 177-187.

Lee, C., Kang, S. K., Long, P., \& Reisinger, Y. (2010). Residents' perceptions of casino impacts: A comparative study. Tourism Management, 31, 189-201.

Lee, S., Seo, K., \& Sharma, A. (2013). Corporate social responsibility and firm performance in the airline industry: The moderating role of oil prices. Tourism Management, 38, 2030.

Lee, T. H. (2011). How recreation involvement, place attachment and conservation commitment affect environmentally responsible behavior. Journal of Sustainable Tourism, 19, 895-915.

Lee, T. H. (2013). Influence analysis of community resident support for sustainable tourism development. Tourism Management, 34(1), 37-46.

Lee, T. H., Jan, F.-H., \& Yang, C.-C. (2013). Conceptualizing and measuring environmentally responsible behaviours from the perspective of community-based tourists. Tourism Management, 36, 454-468.

Lee, W. H., \& Moscardo, G. (2005). Understanding the impact of ecotourism resort experiences on tourists' environmental attitudes and behavioural intentitions. Journal of Sustainable Tourism, 13(6), 546-565. 
Lee, Y.-K., Kim, Y., Lee, K. H., \& Li, D. (2012). The impact of CSR on relationship quality and relationship outcomes: A perspective of service employees. International Journal of Hospitality Management, 31, 745-756.

Lichtenstein, D. R., Drumwright, M. E., \& Braig, B. M. (2004). The effect of corporate social responsibility on customer donations to corporate-supported nonprofits. Journal of Marketing, 68(4), 16-32.

Long, P. T., Perdue, R., \& Allen, L. (1990). Rural resident tourism perceptions and attitudes by community level of tourism. Journal of Travel Research, 28, 3-9.

Lord, T., Greenidge, D., \& Devonish, D. (2011). Local residents' perception of the impacts of the ICC Cricket World Cup 2007 on Barbados: Comparisons of pre and post games. Tourism Management, 32, 349-356.

Luo, X., \& Bhattacharya, C. B. (2006). Corporate social responsibility, customer satisfaction, and market value. Journal of Marketing, 70(4), 1-18.

Maignan, I., Ferrell, O. C., \& Ferrell, L. (2005). A staekholder model for implementing social responsibility in marketing. European Journal of Marketing, 39(9/10), 956-977.

Mehrabian, A., \& Russell, J. A. (1974). An approach to environmental psychology. Cambridge: MIT Press.

Miman, A., \& Pizam, A. (1988). Social impact of tourism on Central Florida. Annals of Tourism Research, 15(2), 208-220.

Nunally, J. C. (1978). Psychometric Theory (2nd ed.). New York, NY: McGraw-Hill.

Nunkoo, R., \& Ramkissoon, H. (2011a). Developing a community support model for tourism. Annals of Tourism Research, 38(3), 964-988.

Nunkoo, R., \& Ramkissoon, H. (2011b). Residents' satisfaction with community attributes and support for tourism. Journal of Hospitality and Tourism Research, 35(2), 171-190.

Nunkoo, R., Gursoy, D., \& Juwaheer, T. D. (2010). Island residents' identities and their support for tourism: An integration of two theories. Journal of Sustainable Tourism, 3, 143154.

Orams, M. B. (1995). Towards a more desirable form of ecotourism. Tourism Management, 16(1), 3-8.

Pearce, L. P. (1996). From culture shock and culture arrogance to culture exchange: Ideas towards sustainable socio-cultural tourism. Journal of Sustainable Tourism, 3, 143-154.

Pfeffer, J., \& Salancik, G. R. (1978). The external control of organization: A resource dependence perspective. New York: Harper \& Row。

Podsakoff, P. M., MacKenzie, S. B., Lee, J.-Y., \& Podsakoff, N. P. (2003). Common method biases in behavioral research: A critical review of the literature and recommended remedies. Journal of Applied Psychology, 88(5), 879-903.

Powell, R. B., \& Ham, S. H. (2008). Can ecotourism interpretation really lead to proconservation knowledge, attitude and behavior? Evidence from the Glalpagos Islands. Journal of Sustainable Tourism, 169(4), 467-489.

Ramkissoon, H., Smith, L. D. G., \& Weiler, B. (2013). Relationships between place attachment, place satisfaction and pro-environmental behaviour in an Australian national parks. Journal of Sustainable Tourism, 21(3), 434-457.

Ramkissoon, H., Weiler, B., \& Smith, L. D. G. (2012). Place attachment and pro-environmental behaviour in national parks: The development of a conceptual framework. Journal of Sustainable Tourism, 20(2), 257-276.

Ramkissoon, H., Weiler, B., \& Smith, L. D. G. (2013). Testing the dimensionality of place attachment and its relationships with place satisfaction and pro-environmental behaviours: A structural equation modelling approach. Tourism Management, 36, 552566. 
Randle, E. J., \& Hoye, R. (2016). Stakeholder perception of regulating commercial tourism in Victoiran National Parks, Australia. Tourism Management, 54, 138-149.

Responsible Tourism in Destinations. (2002). Capetown Declaration. Retrieved from http://www.icrttourism.org/Capetown.shtml.

Ritchie, J. R. B. (1988). Consensus policy formulation in tourism. Tourism Management, 9, 199-216.

Sautter, E. T., \& Leisen, B. (1999). Managing stakeholders: A tourism planning model. Annals of Tourism Research, 26(2), 312-328.

Schultz, P. W. (2000). Empathizing with nature: the effects of perspective taking on concern for environmental issues. Journal of Social Issues, 56(3), 391-406.

Scott, W. R. (1987). The adolescence of institutional theory. Administrative Science Quarterly, 32(December), 493-511.

Sen, S., \& Bhattacharya, C. B. (2001). Does doing good always lead to doing better? Consumer reactions to corporate social responsibility. Journal of Marketing, 38(2), 225-243.

Sen, S., Bhattacharya, C. B., \& Korschun, D. (2006). The role of corporate social responsibility in strengthening multiple stakeholder relationships: A field experiment. Journal of the Academy of Marketing Science, 34(2), 156-166.

Serenari, C., Leung, Y. F., Attarian, A., \& Franck, C. (2012). Understanding environmentally significan behavioural among whitewater rafting and trekking guides in the Garhwal Himalaya, India. Journal of Sustainable Tourism, 20(5), 757-772.

Singal, M. (2014). Corporate social responsibility in the hospitality and tourism industry: Do family control and finances matter. International Journal of Hospitality Management, 36, 81-89.

Sirgy, J. M., Rahtz, D., Cicic, M., \& Underwood, R. (2000). A method for assessing residents' satisfaction with community-based services: A quality-of-life perspective. Social Indicators Research, 49, 279-316.

Sirgy, M. J., \& Cornwell, T. (2001). Further validation of the Sirgy et al.'s measure of sommunity quality of life. Social Indicators Research, 56, 125-143.

Smith-Sebasto, N. J., \& D'costa, A. (1995). Designing a Likert-type scale to predict environmentally responsible behavior in undergraduate students: A multistep process. Journal of Environmental Education, 27(1),14-20.

Southgate, C., \& Sharpley, R. (2002). Tourism, development and the environment. In R. Sharpley \& D. J. Telfer (Eds.), Tourism development: Concept and issues (pp. 231262). Cleveland, OH: Channel View Publications.

Stern, P. C. (2000). Toward a coherent theory of environmentally significant behavior. Journal of Social Issues, 56(3), 407-424.

Su, L., \& Swanson, S. R. (2017). The effect of destination social responsibility on tourist environmentally responsible behavior: Compared analysis of first-time and repeat tourists. Tourism Management, 60, 308-321.

Su, L., Huang, S., \& Huang, J. (2016). Effects of destination social responsibility and tourism impacts on residents' support for tourism and perceived quality of life. Journal of Hospitality and Tourism Research, In press.

Su, L., Huang, S., van der Veen, R., \& Chen, X. (2014). Corporate social responsibility, corporate reputation, customer emotions and behavior intentionsL A structural equation modeling analysis. Journal of China Tourism Research, 10(4), 511-520.

Thapa, B. (2010). The mediating effect of outdoor recreation participation on environmental attitude-behavior correspondence. Journal of Environmental Education, 41(3), 133150.

Tosun, C. (2002). Host perceptions of impacts: A comparative tourism study. Annals of Tourism Research, 29, 231-253. 
Turban, D. B., \& Greening, D. W. (1997). Corporate social performance and organizational attractiveness to prospective employees. Academy of Management Journal, 40(3), 658672.

Var, T., \& Kim, Y. (1989). Measurement and findings on the tourism impact. Department of Recreation, Park and Tourism Sciences. Texas A \& M Univesity.

Vargas-Sa'nchez, A., Plaza- Mejı'a, M, \& Porras-Bueno, N. (2009). Understanding residents's attitudes toward the development of industrial tourism in a former mining community. Journal of Travel Research, 47, 373-387.

Vargas-Sa'nchez,A., Porras-Bueno, N., \& Plaza- Mej1'a, M. (2011). Explaining residents' attitudes to tourism: Is a universal model possible? Annals of Tourism Research, 38(2), 460-480.

Waligo, V. M., Clarke, J., \& Hawkins, R. (2013). Implementing sustainable tourism: A multistakeholder involvement management framework. Tourism Management, 36, 342-353.

Walsh, G., \& Bartikowski, B. (2013). Exploring corporate ability and soical responsibiity associations as antecedents of customer satisfaction cross-culturally. Journal of Business Research, 66(8), 989-995.

Wang, S., Fu, Y., Cecil, A.K., , \& Avgoustis, S. H. (2006). Residents' perceptions of cultural tourism and quality of life: A longitudinal approach. Tourism Today, 5, 47-61.

Weaver, D., \& Lawton, L. (2001). Resident perceptions in the urban-rural fringe. Annals of Tourism Research, 28, 349-358.

Yuksel, F., Bramwell, B., \& Yuksel, A. (1999). Stakeholder interviews and tourism planning in Pamukkale, Turkey. Tourism Management, 20, 351-360.

Zammuto, R. F. (1984). A comparison of multiple constituency models of organizational effectiveness. Academy of Management Review, 9, 606-616. 


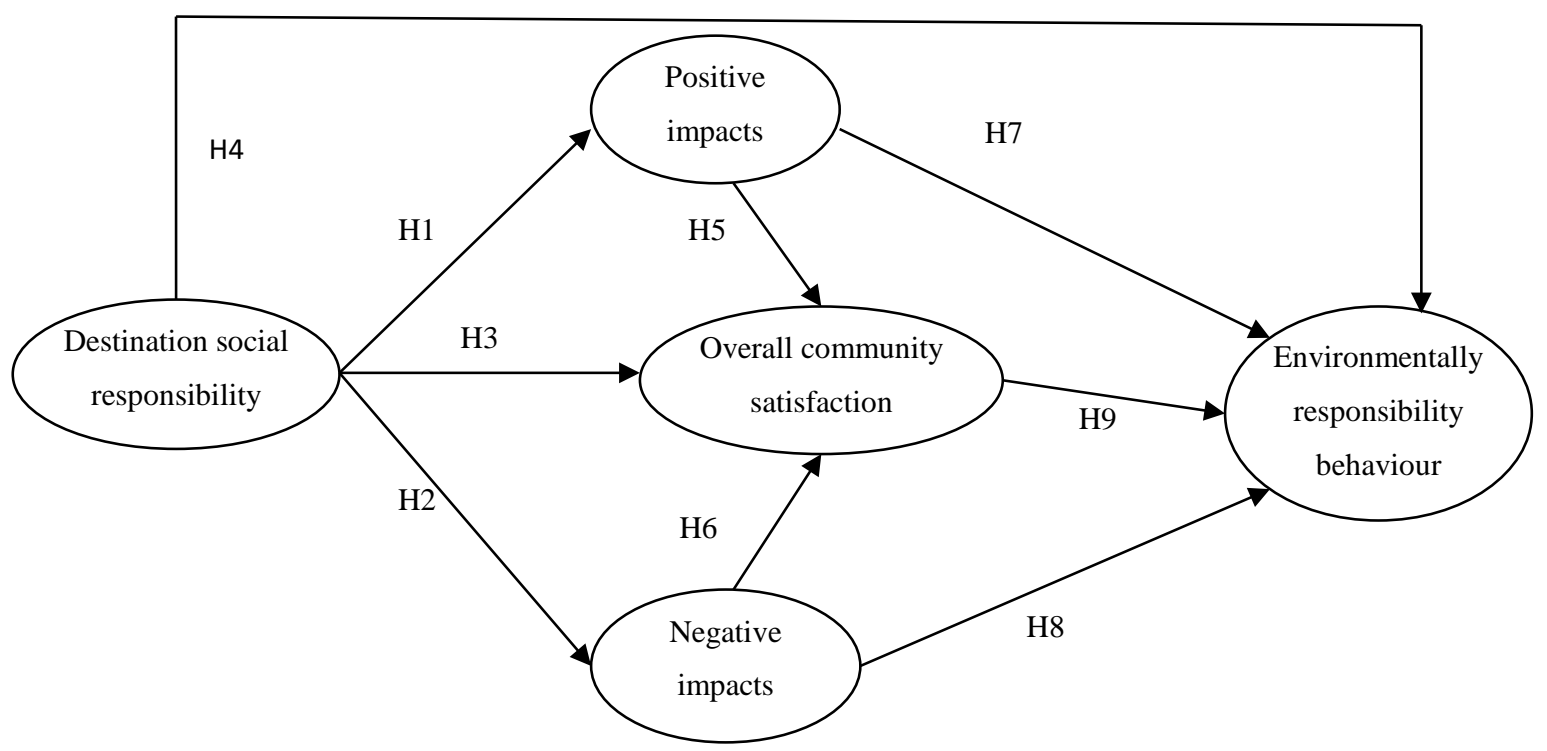

Figure 1: The proposed model 


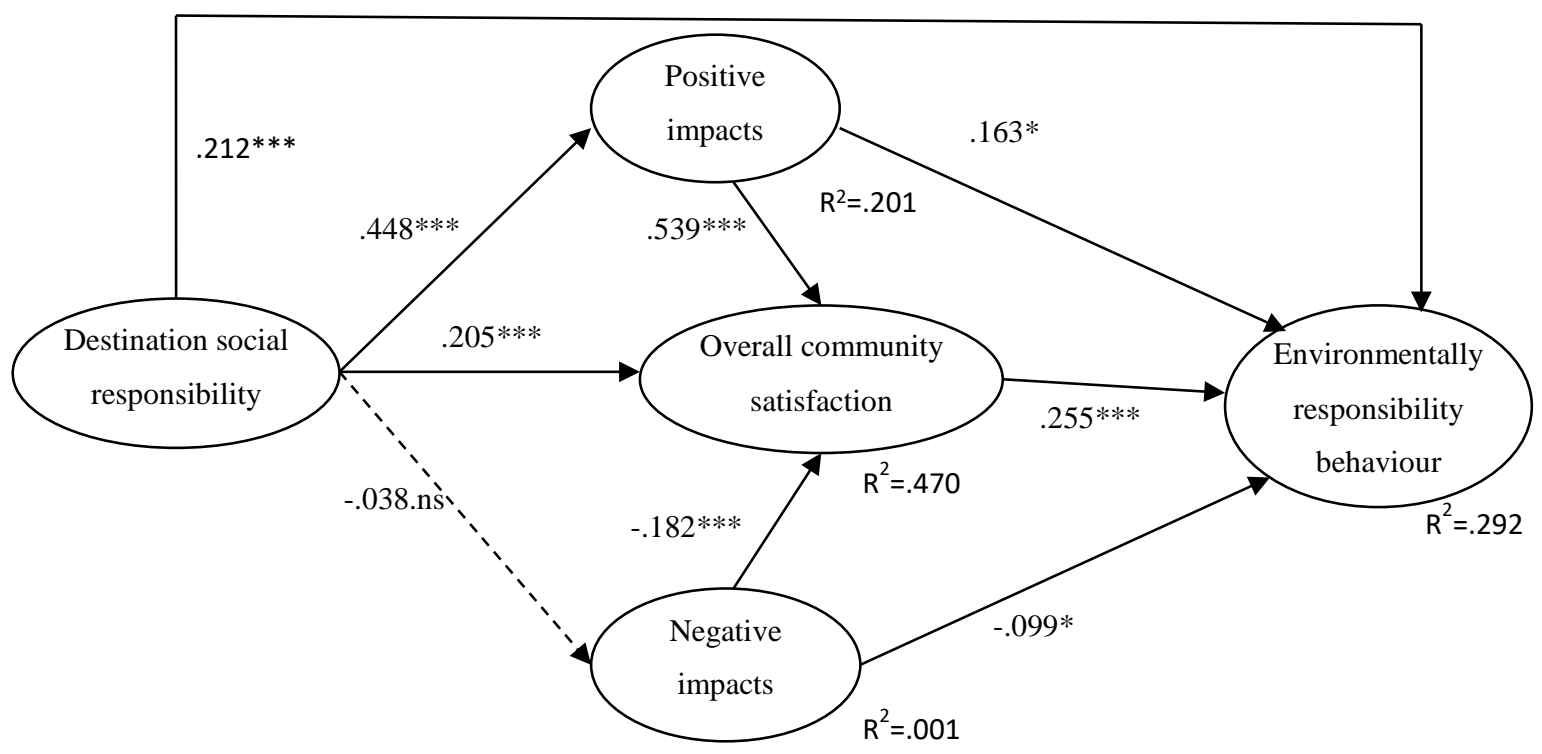

Figure 2: Results of structural model

Notes: * means significant at the level of .05; *** means significant at the level of .001; ns means not significant at the level of .05. 
Table 1: Socio-economic and Demographic Characteristics of Respondents

\begin{tabular}{|c|c|c|c|c|c|}
\hline Characteristic & $\mathbf{N}$ & $\%$ & Characteristic & $\mathbf{N}$ & $\%$ \\
\hline Age & & & Monthly income* & & \\
\hline 18 to 24 & 127 & 28.0 & $\begin{array}{l}\text { Less than RMB } 3000 \\
\text { (US\$436) }\end{array}$ & 64 & 14.1 \\
\hline 25 to 44 & 152 & 33.6 & $\begin{array}{l}\text { RMB } 3000 \text { (US\$436) to } 3999 \\
\text { (US\$581) }\end{array}$ & 128 & 28.3 \\
\hline 45 to 64 & 118 & 26.0 & $\begin{array}{l}\text { RMB } 4000 \text { (US\$581) to } 4999 \\
\text { (US\$726) }\end{array}$ & 109 & 24.1 \\
\hline \multirow[t]{2}{*}{65 or older } & 56 & 12.4 & $\begin{array}{l}\text { RMB } 5000 \text { (US\$726) to } 5999 \\
\text { (US\$871) }\end{array}$ & 78 & 17.2 \\
\hline & & & RMB 6000 (US\$871) or more & 74 & 16.3 \\
\hline Gender & & & Level of education & & \\
\hline Male & 221 & 48.8 & Less than high school & 39 & 8.6 \\
\hline \multirow[t]{3}{*}{ Female } & 232 & 51.2 & High school/technical school & 136 & 30.0 \\
\hline & & & $\begin{array}{l}\text { Undergraduate/Associate } \\
\text { degree }\end{array}$ & 242 & 53.4 \\
\hline & & & Postgraduate degree & 36 & 7.9 \\
\hline
\end{tabular}

*Exchange rate on 23 November, 2016: US\$ 1 = RMB 6.888 
Table 2: Model fit indicators and associated evaluation criteria

\begin{tabular}{llll}
\hline Fit index & Criteria & Fit index & Criteria \\
\hline$\chi_{2} / \mathrm{df}=2.547$ & $<5.00$ & $\mathrm{RFI}=0.930$ & $>0.900$ \\
$\mathrm{RMR}=0.065$ & $<0.08$ & $\mathrm{IFI}=0.964$ & $>0.900$ \\
$\mathrm{RMSEA}=$ & $>0.900$ & $\mathrm{TLI}=0.956$ & $>0.900$ \\
0.059 & & & \\
$\mathrm{GFI}=0.921$ & $>0.900$ & $\mathrm{CFI}=0.964$ & $>0.900$ \\
$\mathrm{NFI}=0.942$ & $>0.900$ & $\mathrm{AGFI}=$ & $>0.900$ \\
& & 0.894 & \\
\hline
\end{tabular}


Table 3: Results of measurement model

\begin{tabular}{|c|c|c|c|c|c|c|c|}
\hline Item & Mean & SD & SL & $t$ & $\begin{array}{l}\text { Composite } \\
\text { reliability }\end{array}$ & $\begin{array}{l}\text { Average } \\
\text { variance } \\
\text { extracted }\end{array}$ & $\begin{array}{l}\text { Cronbach } \\
\text { Alpha }\end{array}$ \\
\hline \multicolumn{8}{|l|}{ Destination social responsibility } \\
\hline $\begin{array}{l}\text { Gulangyu Island seems to include environmental } \\
\text { concerns in its operations }\end{array}$ & 4.82 & 1.310 & 0.822 & 20.906 & 0.922 & 0.702 & 0.921 \\
\hline $\begin{array}{l}\text { Gulangyu Island seems to give back to the local } \\
\text { community }\end{array}$ & 4.67 & 1.282 & 0.859 & 22.392 & & & \\
\hline $\begin{array}{l}\text { Gulangyu Island seems to be successful in their } \\
\text { profitability }\end{array}$ & 4.78 & 1.249 & 0.837 & 21.496 & & & \\
\hline Gulangyu Island seems to treat its stakeholders well & 4.55 & 1.266 & 0.859 & 22.425 & & & \\
\hline $\begin{array}{l}\text { Gulangyu Island seems to be based on ethical values } \\
\text { and beyond legal obligations }\end{array}$ & 4.56 & 1.330 & 0.811 & 20.509 & & & \\
\hline \multicolumn{8}{|l|}{ Positive impacts } \\
\hline $\begin{array}{l}\text { Tourism development increased employment } \\
\text { opportunities }\end{array}$ & 4.98 & 1.319 & 0.734 & 17.312 & 0.854 & 0.665 & 0.846 \\
\hline $\begin{array}{l}\text { Tourism development increased availability of } \\
\text { recreational facilities and entertainment }\end{array}$ & 5.55 & 1.264 & 0.795 & 19.291 & & & \\
\hline $\begin{array}{l}\text { Tourism development improved living utilities } \\
\text { infrastructure and public facilities }\end{array}$ & 5.38 & 1.231 & 0.908 & 23.346 & & & \\
\hline \multicolumn{8}{|l|}{ Negative impacts } \\
\hline $\begin{array}{l}\text { Tourism development increased the prices of goods } \\
\text { and services }\end{array}$ & 2.01 & 1.561 & 0.93 & 26.062 & 0.948 & 0.860 & 0.948 \\
\hline Tourism development increased traffic accidents & 2.03 & 1.530 & 0.903 & 24.640 & & & \\
\hline $\begin{array}{l}\text { Tourism development deteriorated environmental } \\
\text { pollution (litter, water, air and noise) }\end{array}$ & 2.13 & 1.596 & 0.944 & 26.535 & & & \\
\hline \multicolumn{8}{|l|}{ Overall community satisfaction ${ }^{a}$} \\
\hline Overall conditions of Gulangyu Island & 5.33 & 1.252 & 0.869 & 22.698 & 0.911 & 0.773 & 0.910 \\
\hline Future conditions of Gulangyu Island in coming years & 5.21 & 1.184 & 0.96 & 23.844 & & & \\
\hline Gulangyu Island as a desirable place to live & 5.18 & 1.248 & 0.872 & 22.827 & & & \\
\hline
\end{tabular}


I comply with relevant regulations to not destroy the

I report to the destination administration any

6.16 1.207

environmental pollution or destruction*

When I see garbage, tree branches, I will put them in the trash bin

If there are environment cleaning activities, I am willing to attend

I try to convince partners to protect the natural

environment on Gulangyu Island

I try to not disrupt the fauna and flora of Gulangyu

5.67

1.261

0.810

19.773

5.42

1.407

0.776

18.610

5.33

1.400

0.746

17.651

6.26

$$
\begin{array}{lll}
1.077 & 0.591 & 12.998
\end{array}
$$

Island during my life

Notes: ${ }^{\text {a }}$ The overall community satisfaction was measured in a slightly different way (from 1= "very dissatisfied" to 7= "very satisfied")

* The item was deleted due to its Standard loading being less than 0.40 
Table 4: Correlation coefficients and average variance extracted

\begin{tabular}{|c|c|c|c|c|c|}
\hline & DSR & $\begin{array}{l}\text { Positive } \\
\text { impacts }\end{array}$ & $\begin{array}{l}\text { Negative } \\
\text { impacts }\end{array}$ & $\begin{array}{l}\text { Overall } \\
\text { community } \\
\text { satisfaction }\end{array}$ & ERB \\
\hline DSR & 0.879 & & & & \\
\hline Positive impacts & $0.448 * * *$ & 0.815 & & & \\
\hline Negative impacts & -0.030 & $-0.211^{* * *}$ & 0.927 & & \\
\hline $\begin{array}{l}\text { Overall community } \\
\text { satisfaction }\end{array}$ & $0.445 * * *$ & $0.657 * * *$ & $-0.284 * * *$ & 0.879 & \\
\hline ERB & $0.401^{* * *}$ & $0.445^{* * *}$ & $-0.208 * * *$ & $0.485 * * *$ & 0.739 \\
\hline
\end{tabular}


Table 5: Structural model test results and hypothesis test outcome

\begin{tabular}{lllllll}
\hline Hypothesis & $\begin{array}{l}\text { Relationship between } \\
\text { variables }\end{array}$ & $\begin{array}{l}\text { Label } \\
\text { of } \\
\text { path }\end{array}$ & $\begin{array}{l}\text { Standard } \\
\text { path } \\
\text { loadings }\end{array}$ & $\begin{array}{l}\text { T- } \\
\text { value }\end{array}$ & SE & $\begin{array}{l}\text { Hypothesis } \\
\text { test } \\
\text { outcome }\end{array}$ \\
\hline $\mathrm{H}_{1}$ & $\begin{array}{l}\text { DSR } \rightarrow \text { Positive } \\
\text { impacts }\end{array}$ & $\lambda_{21}$ & $0.448^{* * *}$ & 8.381 & 0.052 & Yes \\
$\mathrm{H}_{2}$ & $\begin{array}{l}\text { DSR } \rightarrow \text { Negative } \\
\text { impacts }\end{array}$ & $\lambda_{31}$ & -0.038 & -0.757 & 0.073 & No \\
$\mathrm{H}_{3}$ & $\begin{array}{l}\text { DSR } \rightarrow \text { Overall } \\
\text { community }\end{array}$ & $\lambda_{41}$ & $0.205^{* * *}$ & 4.357 & 0.050 & Yes \\
& $\begin{array}{l}\text { satisfaction } \\
\text { DSR } \rightarrow \text { ERB }\end{array}$ & $\lambda_{51}$ & $0.212^{* * *}$ & 3.845 & 0.060 & Yes \\
$\mathrm{H}_{4}$ & $\begin{array}{l}\text { Positive impacts } \rightarrow \\
\mathrm{H}_{5}\end{array}$ & $\beta_{42}$ & $0.539^{* * *}$ & 9.915 & 0.060 & Yes \\
& $\begin{array}{l}\text { Overall community } \\
\text { satisfaction }\end{array}$ & & & & & \\
$\mathrm{H}_{6}$ & $\begin{array}{l}\text { Negative impacts } \rightarrow \\
\text { Overall community }\end{array}$ & $\beta_{43}$ & $-0.182^{* * *}$ & -4.556 & 0.029 & Yes \\
& $\begin{array}{l}\text { satisfaction } \\
\text { Positive impacts } \rightarrow\end{array}$ & $\beta_{52}$ & $0.163^{*}$ & 2.392 & 0.076 & Yes \\
$\mathrm{H}_{7}$ & $\begin{array}{l}\text { ERB } \\
\text { Negative impacts } \rightarrow \\
\text { ERB }\end{array}$ & $\beta_{53}$ & $-0.099^{*}$ & -2.089 & 0.035 & Yes \\
$\mathrm{H}_{8}$ & $\begin{array}{l}\text { Overall community } \\
\text { satisfaction } \rightarrow \text { ERB }\end{array}$ & $\beta_{54}$ & $0.255^{* * *}$ & 3.681 & 0.070 & Yes \\
$\mathrm{H}_{9}$ & & & & & \\
\hline
\end{tabular}

Note: ${ }^{*}$ means significant at the 0.05 level; ${ }^{* * *}$ means significant at the 0.001 level 
Table 6: Direct, indirect and total effects

\begin{tabular}{|c|c|c|c|}
\hline Relationship & $\begin{array}{l}\text { Direct } \\
\text { effect }\end{array}$ & $\begin{array}{l}\text { Indirect } \\
\text { effect }\end{array}$ & $\begin{array}{l}\text { Total } \\
\text { effect }\end{array}$ \\
\hline DSR $\rightarrow$ Positive impacts & $0.448 * * *$ & -- & $0.448 * * *$ \\
\hline DSR $\rightarrow$ Negative impacts & -0.038 & -- & -0.038 \\
\hline DSR $\rightarrow$ Overall community satisfaction & $0.205^{* * *}$ & $0.248 * * *$ & $0.453 * * *$ \\
\hline $\begin{array}{l}\mathrm{DSR} \rightarrow \text { Environmentally responsible } \\
\text { behaviour }\end{array}$ & $0.212 * * *$ & $0.193^{* * *}$ & $0.405^{* * *}$ \\
\hline $\begin{array}{l}\text { Positive impacts } \rightarrow \text { Overall community } \\
\text { satisfaction }\end{array}$ & $0.539 * * *$ & -- & $0.539 * * *$ \\
\hline $\begin{array}{l}\text { Positive impact } \rightarrow \text { Environmentally } \\
\text { responsible behaviour }\end{array}$ & $0.163 *$ & $0.138 * * *$ & $0.301 * * *$ \\
\hline $\begin{array}{l}\text { Negative impacts } \rightarrow \text { Overall community } \\
\text { satisfaction }\end{array}$ & $-0.182 * * *$ & -- & $-0.182 * * *$ \\
\hline $\begin{array}{l}\text { Negative impact } \rightarrow \text { Environmentally } \\
\text { responsible behaviour }\end{array}$ & $-0.099 *$ & $-0.046 * * *$ & $-0.145 * * *$ \\
\hline $\begin{array}{l}\text { Overall community satisfaction } \rightarrow \\
\text { Environmentally responsible behaviour }\end{array}$ & $0.255^{* * *}$ & -- & $0.255^{* * *}$ \\
\hline
\end{tabular}

